\title{
Protease Inhibitor
}

National Cancer Institute

\section{Source}

National Cancer Institute. Protease Inhibitor. NCI Thesaurus. Code C783.

Any substance that inhibits a protease, an enzyme that breaks peptide bonds. Proteases

are required for many cell processes and inhibition of proteases can inhibit viral

replication, inflammatory responses, proliferation, and tumor growth. 